\title{
CONSTITUIÇÃO, RELIGIÃO, FERIADOS E RACISMO
}

\author{
CONSTITUTION, RELIGION, HOLIDAYS AND RACISM
}

\author{
Ingo Wolfgang Sarlet \\ Jayme Weingartner Neto
}

\section{RESUMO}

A liberdade religiosa, para além da primazia histórica no constitucionalismo ocidental, é direito fundamental consagrado nos textos internacionais e garantida numa série de dispositivos da Constituição Federal do Brasil (CF). No quadro constitucional brasileiro, o programa normativo ancora-se clara e firmemente no pluralismo religioso, o que não apaga, evidentemente, a história de um país que se descreve tradicionalmente como cristão, ainda majoritariamente católico. Se o direito à liberdade religiosa deve ser vocacionado a ser inclusivo e acolher as confissões religiosas minoritárias, é preciso verificar como se efetiva nas práticas das comunidades religiosas de matriz africana. Nessa perspectiva, o texto aborda as disputas político-jurídicas em torno de feriado no dia 20 de novembro, que já é, assim declarado por lei federal desde 2011, o "Dia Nacional de Zumbi e da Consciência Negra", com ênfase nos aspectos constitucionais e, particularmente, no caso de Porto Alegre, capital do Rio Grande do Sul, cujos desdobramentos mais recentes apontavam para a refração religiosa da data, iniciativa legislativa que, nada obstante, foi declarada inconstitucional pelo Tribunal de Justiça do Rio Grande do Sul. Há, outrossim, duas premissas, que serão convocadas ao longo do texto: a violência estrutural da escravidão, que continua a marcar com racismo a vida social e institucional do Brasil; e a vulnerabilidade das comunidades religiosas de matriz africana.

Palavras-chave: Liberdade religiosa. Feriados. Racismo. 


\section{ABSTRACT}

Religious freedom, beyond the historical primacy in Western constitutionalism, is a fundamental right enshrined in international texts and guaranteed in a series of provisions of the Brazilian Federal Constitution (CF). In the Brazilian constitutional framework, the normative programme is clearly and firmly anchored in religious pluralism, which does not, of course, erase the history of a country that has traditionally described itself as Christian, still mostly Catholic. If the right to religious freedom is to be inclusive and to welcome minority religious beliefs, it must be verified as effective in the practices of religious communities of African origin. From this perspective, the text addresses the political and legal disputes surrounding a holiday on November 20, which has already been declared by federal law since 2011, the "Zumbi and Black Awareness National Day", with emphasis on constitutional aspects and, particularly, in the case of Porto Alegre, capital of Rio Grande do Sul, whose most recent developments pointed to the religious refraction of the date, a legislative initiative which, however, was declared unconstitutional by the Rio Grande do Sul State Court of Justice. There are also two premises, which will be summoned throughout the text: the structural violence of slavery, which continues to mark with racism the social and institutional life of Brazil; and the vulnerability of religious communities of African origin.

Keywords: Freedom of religion. Holidays. Racism. 
"Com a fé de quem olha do banco a cena

Do gol que nós mais precisava na trave A felicidade do branco é plena

A pé, trilha em brasa e barranco, que pena

Se até pra sonhar tem entrave

A felicidade do branco é plena

A felicidade do preto é quase (...)

Primeiro, sequestra eles, rouba eles, mente sobre eles

Nega o Deus deles, ofende, separa eles

Se algum sonho ousa correr, cê para ele (...)

Permita que eu fale, não as minhas cicatrizes

Elas são coadjuvantes, não, melhor, figurantes

Que nem devia tá aqui

Permita que eu fale, e não as minhas cicatrizes

Tanta dor rouba nossa voz, sabe o que resta de nóiz?

Alvos passeando por aí

Permita que eu fale, não as minhas cicatrizes

Se isso é sobre vivência, me resumir à sobrevivência

É roubar o pouco de bom que vivi

Por fim, permita que eu fale, não as minhas cicatrizes Achar que essas mazelas me definem é o pior dos crimes

É dar o troféu pro nosso algoz e fazer nóiz sumir (...)

Tenho sangrado demais, tenho chorado pra cachorro Ano passado eu morri, mas esse ano eu não morro".

(Emicida, Album AmarElo, 2019).

\section{INTRODUÇÃo}

A liberdade religiosa, para além da primazia histórica no constitucionalismo ocidental, é direito fundamental consagrado nos textos internacionais e garantida numa série de dispositivos da Constituição Federal. No quadro constitucional brasileiro, o programa normativo ancora-se clara e firmemente no pluralismo religioso, o que não apaga, evidentemente, a história de um país que se descreve tradicionalmente como cristão, ainda majoritariamente católico. Se o direito à liberdade religiosa como um todo parece apto a harmonizar a maximização da inclusividade (acolher as confissões religiosas minoritárias), num teste de realidade, é preciso verificar como se efetiva nas práticas das comunidades religiosas de matriz africana.

Inviável, neste espaço, investigar os vários contornos do tema, o texto aborda as disputas político-jurídicas em torno de feriado no dia 
20 de novembro, que já é, assim declarado por lei federal desde 2011, o "Dia Nacional de Zumbi e da Consciência Negra", com ênfase nos aspectos constitucionais e, particularmente, no caso de Porto Alegre, capital do Rio Grande do Sul, cujos desdobramentos mais recentes apontavam para a refração religiosa da data, iniciativa legislativa que, nada obstante, foi declarada inconstitucional pelo Tribunal de Justiça do Rio Grande do Sul.

Há duas premissas, que serão convocadas ao longo do texto: a violência estrutural da escravidão, que continua a marcar com racismo a vida social e institucional do Brasil; e a vulnerabilidade das comunidades religiosas de matriz africana. Utiliza-se pesquisa bibliográfica e documental e o horizonte analítico de Boaventura de Sousa Santos, seja na pista das vozes minoritárias silenciadas (sociologia das ausências), seja na senda intercultural da visibilidade das comunidades religiosas de matriz africana (ecologia dos reconhecimentos). Explora-se, ainda, no plano da dogmática constitucional, o quadro das competências legislativas dos entes federados e o conceito de igualdade extensiva, a possibilitar respostas pluralistas na linha da igualdade racial e da afirmação das comunidades tradicionais (e dinâmicas) de matriz africana.

\section{ESCRAVIDÃO, RACISMO E (IN) TOLERÂNCIA RELIGIOSA - UMA TRAJETÓRIA AMARGA E CONFLITUOSA}

Schwarcz e Starling enfatizam, como escândalo resistente, que "a violência está encravada na mais remota história do Brasil, país cuja vida social foi marcada pela escravidão. Fruto da nossa herança escravocrata, a trama dessa violência é comum a toda a sociedade, se espalhou pelo território nacional e foi assim naturalizada" (...) Último país a abolir a escravidão no Ocidente, o Brasil segue sendo campeão de desigualdade social e pratica um racismo silencioso mas igualmente perverso" (SCHWARCZ; STARLING, 2015, p. 14). Pese "uma Constituição avançada - a qual impede qualquer forma de discriminação", identificam a prática de "um preconceito silencioso e perverso, como já se disse, duradouro e enraizado no cotidiano" (SCHWARCZ; STARLING, 2015, p. 19) ${ }^{1}$. 
Mais recentemente, Schwarcz refere-se conjuntamente à escravidão e ao racismo: "No Brasil, o sistema escravocrata transformou-se num modelo tão enraizado que acabou se convertendo numa linguagem, com graves consequências. (...) E, sendo assim, a escravidão foi bem mais que um sistema econômico: ela moldou condutas, definiu desigualdades sociais, fez de raça e cor marcadores de diferença fundamentais, ordenou etiquetas, mando e obediência, e criou uma sociedade condicionada pelo paternalismo e por uma hierarquia muito estrita" (SCHWARCZ, 2019, p. 27-28).

Muitas vezes, um exemplo vale por mil palavras. Maria do Nascimento, hoje com 82 anos, criou-se ouvindo as "tias”, em Ramos, zona norte do Rio de Janeiro, falando em voz baixa e com mágoa sobre "as nossas coisas que estão na polícia”. A menina tornou-se a ialorixá Mãe Meninazinha de Oxum, respeitada mãe de santo do candomblé, à frente do terreiro Ilê Omolu e Oxum, em São João do Meriti, região metropolitana do Rio de Janeiro (CARNEIRO, 2019)². Só muito depois, já adulta, "a ialorixá foi entender que aquelas coisas nas mãos da polícia, sempre cunhadas de 'nossas', eram objetos sagrados do candomblé e da umbanda, que foram apreendidos em batidas policiais em terreiros no início do século, quando religiões de matriz africana eram perseguidas com base em artigos do Código Penal (...) 0 acervo está até hoje nas mãos da polícia: pertence à coleção do Museu da Polícia Civil do Estado do Rio de Janeiro, no prédio que já foi sede do Dops (Departamento de Ordem Política e Social), centro de tortura e repressão durante a ditadura militar".

Quanto à vulnerabilidade das comunidades religiosas de matriz africana, os dados abundam, a começar por referências no STF. O Min. Luís Roberto Barroso, em importante julgamento (STF, RHC 134.682/BA, 1a Turma, Rel. Min. Edson Fachin, j. 29/11/2016), consignou que, mais que tolerância [o tema era possível crime de racismo religioso (Art. 20 da Lei 7.716/89) que teria sido praticado por padre católico contra adeptos do espiritismo e de religiões de matriz africana, ao publicar livro classificado como de "resgate religioso", tendo, por maioria, os Ministros firmado a tese de que o proselitismo constitui núcleo essencial da liberdade de expressão religiosa], trata-se de aceitação do diferente; e que a liberdade de expressão não protege apenas as falas de bom gosto ou com as quais se concorda e agregou uma importante ponderação: "Penso que o único 
e grande limite à liberdade de expressão, como lembrou o Ministro Luiz Fux, está na questão do hate speech, ou seja, as manifestações de ódio, sobretudo, penso eu, quando dirigidas a grupos vulneráveis - portanto, negros, homossexuais -, e aí acho que acende uma liberdade amarela, mesmo no caráter preferencial o qual penso que tem a liberdade de expressão. (...) De modo que não creio que este caso seja um caso em que se aplique a doutrina do hate speech. Ou seja, não acho que os espíritas sejam um grupo historicamente vulnerável para invocar o tipo de proteção que a exceção do hate speech admitiria. E embora considere que a fala do nosso padre ultrapasse todos os limites do erro escusável, não acho, todavia, que ela ultrapasse as fronteiras do crime". A citação serve, pelo inverso, para ilustrar a posição do Min. Barroso no sentido de que negros, em contexto de disputas religiosas, constituem grupos vulneráveis ${ }^{3}$.

Mais recentemente, no julgamento do Recurso Extraordinário no 494.601-RS, o Relator, Min. Marco Aurélio, consignou: "A laicidade do Estado não permite o menosprezo ou a supressão de rituais religiosos, especialmente no tocante a religiões minoritárias ou revestidas de profundo sentido histórico e social, como ocorre com as de matriz africana" (certo que inviável tratamento privilegiado se ausente diferenciação fática a justificá-lo).

Na mesma ocasião, o Min. Edson Fachin, ao valorizar o "patrimônio cultural imaterial", asseverou que as práticas e rituais relacionados ao sacrifício de animais das religiões de matriz africana "constituem os modos de criar, fazer e viver de diversas comunidades religiosas e se confundem com a própria expressão de sua identidade" - sendo tal diretriz interpretativa decorrente da obrigação imposta ao Estado brasileiro no que tange às manifestações culturais afro-brasileiras (art. 215, § 1을 $\mathrm{CF}$ ), pois "elas constituem os modos de ser e viver de suas comunidades, mas também porque a experiência da liberdade religiosa é, para essas comunidades, vivenciada a partir de práticas não institucionais". Portanto, essa "dimensão comunitária da liberdade religiosa" merece proteção constitucional, que deve ser ainda mais forte para o "caso da cultura afro-brasileira, não porque seja um primus inter pares, mas porque sua estigmatização, fruto de um preconceito estrutural - como, aliás, já reconheceu esta Corte (ADC 41, Rel. Min. Roberto Barroso, Pleno, DJe 
16.08.2017) -, está a merecer especial atenção do Estado". Finalmente, a interpretação constitucional dada [ao dispositivo da lei estadual de proteção aos animais do Rio Grande do Sul] não ofende a igualdade: "ao contrário, vai a seu encontro, a designação de especial proteção a religiões de culturas que, historicamente, foram estigmatizadas" ${ }^{4}$.

Em números, de acordo com o Censo Demográfico IBGE 2000/2010 (o mais recente disponível), num país substancialmente cristão, em que "o pastor sobe e o padre desce" (123,2 milhões de católicos, uma queda [inédita] em números absolutos no intervalo de uma década [uma diminuição de 9 pontos percentuais, de 73,6\% para 64,6\%]; 42,2 milhões de evangélicos saltaram de $15,4 \%$ para $22,2 \%$ - seriam 45 milhões, atualmente), as religiões de matriz africana (umbanda e candomblé, as principais) representam $0,3 \%$ da diversidade religiosa brasileira, cerca de 600.000 adeptos, bem abaixo dos espíritas (3,8 milhões) e dos sem religião (15,3 milhões). ${ }^{5}$

Levantamento posterior, realizado pelo Instituto de Pesquisas Datafolha em 2013, conserva os cristãos em ampla maioria de 85\%, porém divididos entre católicos (57\%), evangélicos pentecostais (19\%) e não pentecostais (9\%), ao passo que os espíritas kardecistas comparecem com $3 \%$ e os umbandistas com 1\%. Com relação ao hábito de frequentar a igreja, cultos ou serviços religiosos, 95\% dos entrevistados responderam ter esse costume (a frequência varia de semanal a anual). ${ }^{6}$

Resultados preliminares do Relatório sobre Intolerância e Violência Religiosa no Brasil (2011-2015) indicam que foram registrados 965 casos de intolerância religiosa no país no período, numa curva que cresceu anualmente (FONSECA; ADAD, 2016). Em resposta, em abril de 2016, o Comitê Nacional de Respeito à Diversidade Religiosa divulgou nota pública que destacava a "polarização e a intolerância no debate político, que têm ocorrido nos dias atuais", também presentes na seara religiosa, "alimentadas por lideranças religiosas que cultivam preconceitos e discursos do ódio"; daí a preocupação com ameaças à legalidade e ao Estado democrático de direito, referindo que "agentes de órgãos do Estado brasileiro agem ao arrepio da lei e da Constituição, flertando com o arbítrio e com a exceção", e o repúdio à criminalização dos agentes de direitos humanos, de indivíduos e de coletividades" ${ }^{7}$. No mesmo ano de 
2016, em dezembro, o Ministério dos Direitos Humanos (em parceria com a OAB/SP) promoveu o "Seminário sobre Estado laico, intolerância e diversidade religiosa”. Na abertura, a jurista Flávia Piovesan destacou que se trata de temática central para a Secretaria Especial de Direitos Humanos, seja pela agenda local (constatado aumento sensível das ocorrências de intolerância, com especial preocupação em face das religiões de matriz africana), seja pelo contexto global, um cenário desafiador no qual "há o fortalecimento do discurso do ódio que se ambienta e se exterioriza, tornando-se um discurso cada vez mais veemente" (PIOVESAN, 2018).

Na sua mais recente e já citada obra, Lilia Schwarcz anotou: "Uma profusão de estatísticas oficiais demonstram como as populações afrobrasileiras são objeto dileto da 'intersecção' de uma série de marcadores sociais da diferença que acabam condicionando, negativamente, sua inclusão na sociedade, com um acesso mais precário à saúde, ao emprego, à educação, ao transporte e à habitação"; "0 certo é que as ocorrências de intolerância religiosa cresceram 171\% em relação ao total dos três meses anteriores, as de homofobia $75 \%$ e as de intolerância por origem 83\%. Já os registros relacionados a preconceito de cor e raça subiram 15\%. Os dados do Disque 100 - canal de denúncia do governo - indicam que as religiões mais atacadas foram as de matriz africana, que se converteram em alvo de quase $35 \%$ dos casos do primeiro semestre de 2018. Perseguição, invasão de terreiros, destruição de objetos votivos, fazem parte, infelizmente, das histórias dos candomblés no Brasil. No entanto, se a religião foi oficializada ainda nos tempos de Getúlio Vargas, tem sido particularmente agredida em nosso contexto" (Grifo nosso) (SCHWARCZ, 2019, pp. 175 e 218, respectivamente).

E a invisibilidade? Outra vez, um exemplo, fornecido por Flavia Lima, Ombudsman da Folha de São Paulo: "Em homenagem ao Dia da Criança, no último sábado, o Correio Braziliense publicou fotos de 27 crianças sob o título 'Elas são o futuro do Brasil'. Todas elas eram brancas. Após protestos de leitores, o jornal veio a público pedir desculpas. Recorrendo à ideia de um país miscigenado, reconheceu o erro como 'gravíssimo'8 . 0 retrato escolhido pelo principal jornal de Brasília dialoga, ainda que de modo inconsciente, com algo em que acreditavam alguns intelectuais no fim do século 19: a ideia de que a miscigenação embranqueceria 
o país e o faria avançar no processo civilizatório. Mais de um século depois, o Brasil tem uma cara muito diferente. Segundo dados do IBGE (Instituto Brasileiro de Geografia e Estatística), os negros - a soma dos que se declaram pretos e pardos - representam $56 \%$ da população. A despeito disso, a imagem que a imprensa continua fazendo do país é majoritariamente branca. Por quê?" (LIMA, 2019). ${ }^{9}$

Para tentar responder a pergunta, ajuda Boaventura de Sousa Santos, ao pensar os direitos humanos, no século XXI, "como simbolizando o regresso do cultural e mesmo do religioso", quer dizer, é falar de “diferenças, de fronteiras, de particularismos" (SANTOS, 2010, p. 437). Epistemologicamente, Boaventura propõe uma racionalidade cosmopolita que supere a "razão indolente" que só alcança a compreensão ocidental do mundo e faz a crítica da razão metonímica, "obcecada pela ideia de totalidade sob a forma da ordem", a sufragar dicotomias hierárquicas (civilizado/primitivo, branco/negro, moderno/tradicional, dentre outras) (SANTOS, 2010, p. 94-99). Na transição para superá-las, urgente ampliar o mundo e dilatar o presente, objetivo da sociologia das ausências que propõe o autor, para demonstrar que o que não existe é, na verdade, "ativamente produzido como não existente, isto é, como uma alternativa não credível ao que existe". Neste sentido, Boaventura elenca cinco ecologias e, para enfrentar a colonialidade capitalista (e melhor articular igualdade e diferença), convoca a ecologia dos reconhecimentos, liderada, na América Latina, pelos movimentos feministas, indígenas e de afro-descendentes (Grifamos) (SANTOS, 2010, p. 102-111).

Boaventura também trata dos processos identitários no espaçotempo da língua portuguesa, com olhos no pós-colonialismo e na interidentidade, gizando o caráter periférico do colonialismo português, o que vai gerar uma hibridação nos regimes identitários, mas a "corrente que une o colonizador e o colonizado é o racismo" (no estereótipo do selvagem Caliban). No caso português, a questão racial depara-se com o mulato e a mulata [tantos pardos brasileiros]: "A miscigenação não é a consequência da ausência de racismo, como pretende a razão lusocolonialista ou luso-tropicalista, mas é certamente a causa de um racismo de tipo diferente" (SANTOS, 2010, p. 2450). Finalmente, a debilidade do Próspero colonial português facilitou, "sobretudo no caso do Brasil, a 
reprodução de relações de tipo colonial depois do fim do colonialismo, o colonialismo interno" (SANTOS, 2010, p. 275).

\section{FERIADOS RELIGIOSOS E A QUERELA EM TORNO DO "DIA DA CONSCIÊNCIA NEGRA"}

O caso normativo-constitucional dos feriados religiosos e respeito aos dias de guarda, por sua vez, também permanece controverso. Nota Fábio Carvalho Leite que o tema suscita duas questões jurídicas relevantes, o problema de feriados de tal natureza num Estado laico e a dificuldade de as religiões minoritárias obterem tais feriados (LEITE, 2014, p. 395). Pressupondo, aqui, a constitucionalidade de tais feriados, que, aliás, fazem parte do calendário nacional (no viés majoritário, bem entendido), enfrenta-se a segunda dificuldade, focando as assimetrias em torno de um feriado reivindicado por ativistas do movimento negro, o dia 20 de novembro para celebrar Zumbi dos Palmares.

Por um lado, o Estado deve ponderar a tradição cultural (apoiar e incentivar a valorização e a difusão das manifestações culturais) e considerar a "fixação de datas comemorativas de alta significação para os diferentes segmentos étnicos nacionais", a par de proteger as culturas populares, indígenas e afro-brasileiras (Constituição Federal de 1988, art. 215 , § $1^{\mathrm{o}}$ e $2^{\stackrel{o}{o}}$ ). Um programa extenso, como se vê, e complexo.

Por outro, alguma redução de complexidade operou o legislador. Em nível federal, a lei de regência permanece sendo diploma de 1949, a Lei no 662 (cuja redação original previa cinco feriados nacionais -


que acresceu duas datas aos feriados nacionais: $1^{\circ} / 01, \mathbf{2 1 / 4}, 1 \%$ / $5,7 / 9$, 02/11, 15/11 e 25/12.

Já a Lei no 6.802/80 estabeleceu que "é declarado feriado nacional o dia 12 de outubro, para culto público e oficial a Nossa Senhora Aparecida, Padroeira do Brasil". No que tange ao "culto público e oficial", por afronta ao princípio da não confessionalidade, considera-se quase óbvio que a norma não foi recepcionada pela Constituição Federal. 
Já a Lei no 9.093/95, estabeleceu, no art. 1ํㅡ, como feriados civis: I - os declarados em lei federal; II - a data magna do Estado fixada em lei estadual; III - os dias do início e do término do ano do centenário de fundação do Município, fixados em lei municipal. No seu art. $2^{\circ}$ determinou que "são feriados religiosos os dias de guarda, declarados em lei municipal, de acordo com a tradição local e em número não superior a quatro, neste incluído a Sexta-Feira da Paixão".

Assim, alguns feriados religiosos estão definidos em nível nacional (sexta-feira santa, 12/10, 02/11 e 25/12), remanescendo aos Municípios, a vingar determinada leitura constitucional da competência legislativa dos entes federados, a determinação de outros três feriados religiosos, de acordo com a tradição local (já que o quarto, assegurou o comando federal, é a "Sexta-Feira da Paixão", data cristã).

A questão não se pacificou.

E Zumbi, neste interregno, como símbolo de nossas ambiguidades e ancoragem miscigenada, como tem se comportado?

A Lei Federal no 12.519, de 10/11/2011, instituiu o "Dia Nacional de Zumbi e da Consciência Negra, a ser comemorado, anualmente, no dia 20 de novembro, data do falecimento do líder negro Zumbi dos Palmares" (art. $1^{\circ}$ ). As discussões, na Câmara dos Deputados, remontam a projetos de 2002 e 2003, que visavam tornar o dia 20 de novembro feriado. Quanto à Lei 12.519, decorre dos Projetos de Lei no 4.437/2004 e no 5.352/2007, ambos oriundos do Senado Federal (Senadores Serys Slhessarenko e Paulo Paim, respectivamente): o primeiro limitava-se a marcar o dia como celebração do Zumbi e da consciência negra, ao passo que o segundo instituía novo feriado nacional. 0 projeto, com o feriado, foi aprovado na Comissão de Educação e Cultura da Câmara dos Deputados em 20/9/2005. A Comissão de Constituição e Justiça e de Cidadania da Câmara dos Deputados, em 26/11/2008, opinou favoravelmente ao feriado. Houve um voto em separado (Deputado Regis de Oliveira), favorável à celebração do dia mas contrário a transformá-lo em feriado nacional, pois, apesar "de o grande líder negro merecer totalmente essa honraria, entendo que temos muitos feriados no Brasil, circunstância que compromete o funcionamento das indústrias e causa imensurável prejuízo às atividades comerciais do país", além do que seria desnecessário o 
feriado para lembrar do "verdadeiro símbolo da igualdade racial" que, confirmando a crença da população na sua imortalidade, estará sempre presente nas "mentes e corações dos brasileiros pelos seus ideais de liberdade". Como visto, essa a concepção que acabou prevalecendo e o "dia de folga" pegou apenas parcialmente. ${ }^{10}$

Em face das incertezas, foi apresentado, na Câmara dos Deputados, em 10/02/2015 o Projeto de Lei 296/2015, pelo qual o "Dia Nacional da Consciência negra, 20 de novembro, passa a ser considerado feriado nacional a ser celebrado anualmente" (acrescentando oitava data à enumeração da Lei no 662/1949), visando "manter viva a lembrança de resistência do povo escravizado. Nesta data, em 1695, foi morto o herói dos negros, Zumbi dos Palmares, símbolo da persistência na luta de seu povo contra a escravidão. Essa resistência transcende a questão da libertação e do confronto direto com os senhores de escravos, ela percorre aspectos culturais e religiosos. A liberdade para praticar a religião de matiz africana e a capoeira, por exemplo, lhes era negada, pois a sociedade brasileira, predominantemente católica, repudiava os costumes do povo afrodescendente"11. 0 projeto foi também aprovado na Comissão de Constituição e Justiça e de Cidadania, que outra vez destacou que tal perspectiva também se ampara na liberdade religiosa, verbis: “Toda essa perspectiva também se ampara na liberdade religiosa, como bem apontado no Parecer da Deputada Jandira Feghali, na Comissão de Cultura. É sabido que as religiões de matizes africanas são desvalorizadas e desconsideradas pelo status quo, fazendo do feriado um momento de exposição e reconhecimento da pluralidade existente em nossa esfera pública. Em outros países de história pluralística, tais como os Estados Unidos da América e o Canadá, esses feriados existem para comemorar a diversidade existente. Nos EUA, temos o Martin Luther King Day (Dia de Martin Luther King), para comemorar a história e luta do povo negro; e, no Canadá, temos o Aboriginal Day (dia dos Aborígenes), para comemorar a história indígena que perpassa a cultura canadense".

O projeto, todavia, foi rejeitado pela Comissão de Desenvolvimento Econômico, Indústria, Comércio e Serviços, em 13/9/2016. 0 relator, Deputado Mauro Pereira, ateve-se ao "mérito econômico da iniciativa", num "momento de aguda crise econômica", pois "já convivemos com 
um grande número de feriados, somados os federais, os estaduais e os municipais", sendo fato insofismável que a "celebração de feriados, inobstante sua relevância e propriedade, gera prejuízos à economia". ${ }^{12}$ Persiste, portanto, a situação nebulosa.

Lei Municipal do Rio de Janeiro instituiu 20 de novembro como feriado municipal. Embora o Tribunal de Justiça do Estado tenha considerado a escolha inconstitucional, o STF, no RE 251.470-5 (Rel. Min. Marco Aurélio, 24/5/2000), considerando que a ação originária confrontara a lei municipal com a legislação federal (Lei no 9.093/95), asseverou a impossibilidade jurídica do pedido e recolocou o feriado atacado no calendário citadino.

Lei estadual fluminense (Lei no 4.007/2002), posteriormente, criou feriado estadual; a Representação pela Inconstitucionalidade [da Lei $\mathrm{n}$ o 4.007] no 146/2002 foi julgada improcedente pelo TJRJ, ao argumento de que se trata de "norma suplementar e específica sobre educação e turismo regional, que não se apresenta com natureza de norma geral em matéria de educação e cultura" (Ementa no 15). A Confederação Nacional do Comércio de Bens, Serviços e Turismo (CNC), em 13/6/2008, ajuizou a ADI 4.091, julgada extinta sem resolução de mérito em 06/9/2017 pelo Min. Rel. Alexandre de Moraes, ausente a legitimidade ativa da requerente ${ }^{13}$.

No Paraná, o Tribunal de Justiça decidiu, por maioria de votos, na ADI 1011923-6 (Órgão Especial, 21/11/2014), declarar Lei Municipal de Curitiba, que instituía o feriado de 20 de novembro em homenagem ao "Dia Nacional da Consciência Negra", inconstitucional, por invadir competência privativa da União, ao legislar sobre temas relacionados com o Direito do Trabalho e por ter contrariado a referida Lei Federal no 9.093/95, que atuaria como "bloqueio de competência" (refração religiosa).

Cogita-se que releitura do símbolo Zumbi, no contexto dos quilombos e associada ao candomblé, permitiria, numa ecologia de reconhecimento, suplantar a lacuna que a sociologia das ausências ajuda a explicar, aliás caminho intentado recentemente pelo legislador municipal em Porto Alegre, pese tenha sido, novamente, cortado pelo Poder Judiciário, como se passa a detalhar. 
No Rio Grande do Sul, desde 2003, leis municipais, têm sido invalidadas pelo Poder Judiciário, ao argumento básico de que a data objeto do feriado não envolve "dia de guarda" de acordo com a tradição local, falecendo aos Municípios, portanto, competência legislativa.

Tome-se Porto Alegre como emblema. A Lei Municipal no 9.252, de 03/11/2003, declarava feriado o dia 20 de novembro, "em homenagem ao Dia da Consciência Negra". A Ação Direta de Inconstitucionalidade noㅡ 70007609308 proposta pela Federação das Indústrias do Estado do Rio Grande do Sul (FIERGS) foi julgada procedente em 18/10/2004. Extraise o cerne da ementa: A COMPETÊNCIA DO MUNICÍPIO PARA INSTITUIR FERIADOS SE RESTRINGE AOS RELIGIOSOS EM NÚMERO NÃO SUPERIOR A QUATRO, AÍ INCLUÍDA A SEXTA-FEIRA SANTA, DE ACORDO COM A TRADIÇÃO LOCAL - INTERPRETAÇÃO DA LEI № 9.093/95 QUE ATUA NA ESPÉCIE COMO $\square$ BLOQUEIO DE COMPETÊNCIA $\square \square$ INVASÃO DA COMPETÊNCIA EXCLUSIVA DA UNIÃO PARA LEGISLAR SOBRE DIREITO DO TRABALHO E INSTITUIR FERIADO CIVIL - INCONSTITUCIONALIDADE QUE SE OSTENTA ANTE OS ARTIGOS 8ํ E 13 DA CONSTITUIÇÃO ESTADUAL E 22, I E 30, I, DA CONSTITUIÇÃO FEDERAL. ${ }^{14}$

Pois bem. Cerca de dez anos depois, a Câmara de Vereadores retoma o tema, no Projeto de Lei no 365/2013, cuja primeira versão apenas declarava o dia 20 de novembro (Dia da Consciência Negra, conforme a Lei Federal no 12.519/2011 e Lei Estadual no 8.352/1987) feriado municipal. ${ }^{15} 0$ texto foi aprovado na Casa Legislativa, mas sofreu veto total do Chefe do Poder Executivo, comunicado em 06 de janeiro de 2015, ratificando o bloqueio de competência e a inconstitucionalidade já declarada da lei municipal de 2003. Nas razões, o Prefeito José Fortunati ressalta que o feriado é "de caráter civil e não religioso, como se pode perceber na sua exposição de motivos" (que, de fato, nada referia a respeito); as decisões judiciais foram claras quanto ao feriado de 20 de novembro, "pois não há caráter religioso, não se constituindo de 'dia de guarda' como requer a Lei Federal no 9.093, de 1995”.

Entretanto, ao final do ano, num giro, o mesmo Prefeito sancionou a Lei no 11.971 , de 11/12/2015. 0 veto de janeiro teve como base parecer da Procuradoria Geral do Município, que, dentre outros argumentos, alertava que a nova data só poderia ser instituída se um dos quatro feriados 
municipais já existentes fosse banido do calendário da cidade: Corpus Christi, Sexta-Feira da Paixão, Finados ou Nossa Senhora dos Navegantes. A solução encontrada pelo autor do novo projeto (Projeto de Lei no 65/2015, o mesmo Vereador Delegado Cleiton, Exposição de Motivos de 19/3/2015) foi eliminar do calendário municipal o 2 de novembro (Dia de Finados), pois este já é um feriado nacional. Sanada a ilegalidade (pois atendido o art. $2^{\circ}$ da Lei Federal no 9.093/95), ponderava o vereador proponente, a inconstitucionalidade seria contornada em duplo movimento: ao reinterpretar, com amplitude maior, a competência dos Municípios para legislar sobre assuntos de interesse local (art. 30, I, CF), o que não se chocaria com os artigos 8 e 13, I e II, da Constituição Estadual do Rio Grande do Sul, que não seriam restritivos; e ao apostar que o 20 de novembro se enquadraria entre os religiosos, tanto que o nome consagrado para a data foi Dia da Consciência Negra e da Difusão da Religiosidade. ${ }^{16}$

Nesta ótica, o projeto logrou aprovação e virou a Lei Municipal no 11.971, de 11 de dezembro de 2015.

Contudo, em novembro de 2016, o Tribunal de Justiça do Rio Grande do Sul afastou a conotação religiosa da data, por "não configurar dia de guarda" e reafirmou a competência privativa da União de legislar sobre direito do trabalho (ADI no 70068409531). Tratava-se de ação direta de inconstitucionalidade proposta pelo Sindicato dos Lojistas do Município de Porto Alegre (SINDILOJAS), que teve como interessada a Federação Afro-Umbandista e Espiritualista do RS (FAUERS).

Em apertada síntese, nos termos da ementa: (i) de acordo com o art. 8ํ da Constituição Estadual, os Municípios devem, necessariamente, observar os princípios estabelecidos na própria Constituição Estadual, além daqueles consagrados na Constituição Federal - dentre eles, o princípio federativo, do qual decorre o estabelecimento de um sistema de repartição de competências entre União, Estados, Distrito Federal e Municípios, inclusive em matéria legislativa. 0 art. 22, inc. I, da Constituição Federal estabelece que compete privativamente à União legislar sobre, no que interessa, direito do trabalho, ao passo que o art. 30, inciso I, da CF/88, preconiza que aos Municípios compete legislar sobre assuntos de interesse local; (ii) induvidoso que a instituição de feriados constitui- 
se temática ligada ao Direito do Trabalho - uma vez que o feriado, independentemente de seu cunho e natureza civil ou religiosa, ao fim e ao cabo, implica a interrupção do trabalho; (iii) a União editou lei federal, a Lei n. $9.093 / 95$, regendo a matéria, prevendo a possibilidade de os Municípios declararem feriados religiosos os dias de guarda, de acordo com a tradição local e em número não superior a quatro, já incluída a SextaFeira da Paixão (art. 2º da Lei n.o 9.093/95); (iv) o dia 20 de novembro, declarado como feriado municipal pela lei impugnada, consagrado ao "Dia da Consciência Negra e da Difusão da Religiosidade", não constitui dia de guarda, não podendo ser enquadrado como feriado religioso, por exclusão, tem-se que o feriado seria de natureza civil, porém, somente lei federal poderia assim declará-lo (art. 1ํ, inc. I, da Lei n.o 9.093/95); (v) assim, flagrante a inconstitucionalidade da lei impugnada, por afronta ao art. 8º da Constituição Estadual e aos art. 22, inc. I, e 30, inc. I, ambos da Constituição Federal, destacando-se que estes dois últimos dispositivos configuram norma de reprodução obrigatória ${ }^{17}$.

Vale seguir alguns pontos. 0 voto do Relator começa destacando que o Tribunal já analisara, em controle concentrado de constitucionalidade, lei do município de Porto Alegre que declarava o feriado municipal em 20 de novembro, em homenagem ao "Dia da Consciência Negra” (decisão pela inconstitucionalidade, de 2004, já mencionada). Portanto, com a mesma estrutura argumentativa, a conclusão foi pela procedência. 0 Relator citou parecer da Procuradoria-Geral de Justiça, que definia dias de guarda como "aquelas datas de grande importância para determinada religião, em que os fiéis se dedicam à oração, à celebração de ritos, à caridade, a jejuns, a boas obras, a comemorações conforme a tradição ou à reflexão, não sendo este o caso em análise, já que inexiste indicativo de que o dia 20 de novembro seja de fundamental significado para qualquer denominação religiosa". Com tal premissa [que reza no altar das confissões tradicionalmente majoritárias, como se vê da mera enumeração de exemplos, a emular a Igreja Católica], consoante o parecer: patente que a inclusão da expressão Difusão da Religiosidade [termo extremamente vago e genérico] objetivou apenas conferir um verniz de constitucionalidade ao feriado, criando a falsa impressão de que se trataria de data também com cunho religioso. Em verdade, a ideia de "religiosidade" - como consta da Lei Municipal - 
valoriza o aspecto sociológico do tema, vez que apenas faz referência a um fenômeno humano geral, sem especificar nenhuma orientação religiosa particular merecedora de homenagem. Assim, não há como se atribuir, por si só, como pretende a municipalidade, natureza religiosa ao feriado em tela, na medida em que o Dia da Consciência Negra, por óbvio, objetiva homenagear a população afrodescendente, não parecendo ser possível, deste modo, emprestar à data um caráter de feriado religioso ou mesmo de conotação religiosa, que pressupõe, em seu sentido mais básico, a relação do ser humano com o sagrado, o transcendente ou o misterioso. O Relator adere: "essa alusão [à Difusão da Religiosidade], por si só, não traz à data contorno de feriado religioso". Em nossa leitura, a religiosidade a ser difundida, no contexto legislativo, é evidentemente a afro-brasileira.

A primeira divergência, inaugurada pelo Des. Rui Portanova, principia por apontar a necessidade de seguir decisão do STF (o já citado RE no 251.470/RJ), que chegou a ser discutida na decisão do TJRS de 2004. Depois, critica a "extensão inusitada" dada ao artigo 8 da Constituição Estadual, retirando-se "à fórceps" a invasão local da competência da União para legislar sobre direito do trabalho, estratégia da parte autora que tem dado resultado, mas é reducionista: "Nem a vida se resume a fazer as pessoas trabalharem, nem o feriado se resume a um único efeito laboral", pois sua finalidade é "marcar uma data significativa para a comunidade. É fazer refletir sobre modelos, sobre herois, sobre a tradição. 0 feriado participa de tudo aquilo que transforma um grupo de pessoas em uma comunidade, pois é uma forma de exteriorizar valores comuns". Adiante, afirma que a decisão anterior do TJRS deu-se porque a lei de 2003 não previa um motivo religioso para instituir o feriado. Agora, "com a indicação da 'Difusão da Religiosidade' a lei acaba por cumprir o requisito legal e legitima a atuação legislativa do legislador municipal. Por evidente, não se vá exigir que o feriado religioso municipal, projete o 'dia de guarda' nos moldes, por exemplo, da Religião Católica"18.

Nas entrelinhas, o registro da tensão durante a sessão de julgamento. 0 Des. Irineu Mariani consignou, no seu voto, que "uma sessão de julgamento não é algo que se ganha no grito", referindo manifestações pró e contra e alguma exortação feita pelo Presidente do Tribunal, mas "de pronto veio o desafio. É lamentável que não se comportem da forma que se exige 
numa Corte de Justiça. Então, só cabia mesmo ordenar a saída dos já não assistentes, e sim manifestantes". Prossegue o Desembargador, ainda que se admitisse vincular o "Dia da Consciência Negra” a Zumbi dos Palmares (pese informes históricos de que ele também tinha escravos), não é razoável agregar a esse dia o caráter religioso, artifício, mero pretexto para "passar o verniz da constitucionalidade".

Noutra vertente de divergência, o Des. Voltaire de Lima Moraes baseou-se na autonomia dos entes federados: "não há nenhum dispositivo [no art. 22 da CF] que fale em legislar sobre feriado, tampouco no seu art. 23, quando trata da competência concorrente. (...) não me parece que uma lei infraconstitucional [Lei no 9.093/95] possa estabelecer restrições a um ente federado, em matéria de competência legiferante, no caso ao Município, senão aquelas impostas pela da própria Carta Magna”. Ademais, se de fato estabelecer feriado implica competência legislativa sobre, direito do trabalho, "então o Município jamais poderia legislar sobre feriado religioso".

Talvez a concepção mais plural da questão religiosa tenha sido apanhada pela divergência do Des. Bayard Ney de Freitas Barcellos, o que justifica a longa citação: "na verdade, essa lei [Lei no 9.093/95] que estabelece esse limite de feriados obviamente está baseada numa tradição e numa cultura branca e católica. 0 que é dia de guarda? Que eu saiba só existe basicamente na religião cristã e na vertente católica. E me chama atenção outra exigência: que faça parte da tradição local. Mas o que faz parte da tradição local que não seja a religião católica oficial desde o Império do Brasil? Isso me traz à lembrança o famoso Major Vidigal, Chefe de Polícia do Rio de Janeiro no século XIX, homenageado com o Morro do Vidigal, que costumava patrulhar as favelas dos negros e espancar sumariamente quem ele pegasse praticando o candomblé, jogando capoeira ou fazendo as danças antigas, como a umbigada, que deram origem ao samba, nessa vertente, enquanto a religião católica era a religião oficial do Império, toda a tradição trazida não necessariamente de boa vontade pela população negra era furiosamente reprimida. Aí eu não entendo como alguém, especialmente a comunidade negra, que é grande e é tradicional em Porto Alegre, vai ter algum feriado baseado na tradição local, 
porque não há nenhuma tradição local a respeito de qualquer homenagem à cultura negra. Nesse sentido, este feriado tem, sim, caráter religioso, porque, se antes houve um equívoco em estabelecer uma homenagem a Zumbi dos Palmares, agora, seja lá como for, certo ou errado, foi acrescentada difusão da religiosidade negra, e não cabe a nós, que não somos - pelo menos eu imagino que não - praticantes dessa religiosidade, estabelecer a forma como aproveitarão esse dia. Mas também não vamos estabelecer que eles só poderão aproveitar o feriado em homenagem à cultura deles dentro da matriz branca católica. Eles irão aproveitar para fazer a sua difusão de religiosidade com festividades nos seus terreiros, nos seus locais de religiosidade da forma como bem entenderem. Não somos nós que estabeleceremos os limites e o formato de como isso irá acontecer, mas, certamente, para divulgação e respeito à religiosidade afro-brasileira, nós temos que aceitar, sim, apesar de não ser um dia de guarda em termos católicos, apesar de não estar vinculado a nenhuma tradição. Isso também seria discutível, porque essa religiosidade está vinculada à prática dos povos afro-brasileiros, não necessariamente ao reconhecimento oficial a essa prática. Apenas eles querem agora o reconhecimento oficial de que existe essa religiosidade e que eles podem comemorar e difundir".

Outro voto interessante, de lavra do Des. Ricardo Torres Hermann, menciona que a legislação federal apenas concretiza o mandamento constitucional segundo o qual cabe aos Municípios legislar sobre assunto de interesse local, e faz isso ao dispor que "os feriados religiosos, ou seja, os dias de guarda, são objeto de legislação municipal”. Por quê? “É porque, de fato, as questões religiosas e os costumes religiosos estão ligados a disposições locais. (...) Por isso é que há, sim, invasão de competência quando se pretende dispor sobre feriados cívicos em leis municipais, porque aí não se está diante de matéria estritamente local. Esse é o traço distintivo entre os feriados cívicos e os feriados religiosos". Observação semelhante foi feita pelo Des. Armínio José Abreu Lima da Rosa: "ao legislador Municipal cabe definir feriados religiosos; feriados cívicos são com o legislador federal. E se entende por que essa distribuição, porque o dado religioso é um dado muito local, ao contrário do feriado cívico, que 
chama à nacionalidade"19. Ficaria por demonstrar, entretanto, na linha do raciocínio, mas pela inversa, a constitucionalidade das leis federais que estabelecem feriados nacionais em datas evidentemente religiosas, como o 02 de novembro, a "sexta-feira santa", e o 12 de outubro (para "culto público e oficial a Nossa Senhora Aparecida").

Finalmente, prossegue o Des. Armínio, citando o sociólogo português José Pereira Coutinho, as múltiplas definições de religião podem dividir-se em dois grupos: "substantivas, descritoras do que ela é, da sua essência, das suas crenças e práticas, da experiência do outro ou do sagrado; ou funcionais, referentes ao que ela faz, ao seu papel, à sua função social". Ao ensaiar uma definição essencialista, estabelece a primeira característica da religião: "a ligação do homem com algo superior ou transcendente, o seu objeto", certo que o "contexto cultural influencia sobremaneira a definição de religião". Nas sociedades ocidentais, "onde se associa a religião à relação com algo transcendente, ela é sistema mediador entre o homem e entidades superiores"; nas orientais, não a transcendência, "mas antes o panteísmo, um deus em tudo. Assim, a religião não é ligação a algo superior e transcendente, mas à própria natureza, a todos os seres vivos". Conclui com perguntas: "há algo disso, há algo que minimamente se aproxime disso no feriado destinado à consciência negra? Por mais relevante, por mais respeitável que seja?". Diferentemente, nossa resposta é positiva, ancorados num conceito tipológico de religião. ${ }^{20}$

Neste contexto, quais as perspectivas? Que expectativas normativas poderiam ser convocadas? E até que ponto elas fazem parte da nossa ambígua identidade e inconclusa cidadania?

\section{FERIADOS RELIGIOSOS, DIGNIDADE DA PESSOA HUMANA E PLURALISMO - UMA LEITURA SISTEMÁTICA DO MARCO CONSTITUCIONAL}

Desde logo chama-se a atenção para a dignidade da pessoa humana como premissa antropológica-cultural do Estado Constitucional (HÄBERLE, Peter, 2013, p. 101), a manifestar-se nas liberdades culturais e na democracia pluralista (consequências organizativas - Estado democrático 
de direito), a quem já não compete unificar (integrar) a nação dispersa, mas sim assegurar a inclusividade, de maneira que as diferenças culturais concorram num sistema pluralístico, plasmando a sociedade aberta. Nestes campos, o Estado constitucional há que se afirmar perante os fundamentalismos. Vale dizer, o princípio da não identificação, em rigor, não pode significar neutralidade, visto que o Estado democrático de direito precisa garantir suas premissas, os valores básicos fundamentadores do modelo constitucional, que podem ser chamados (no contexto da hermenêutica diatópica, disposta ao diálogo e na busca de equivalentes homeomórficos) de valores ocidentais aglutinantes, dos quais não há retorno possível, salvo ruptura do Estado constitucional ${ }^{21}$.

Nessa perspectiva, a dignidade humana (de todos os humanos em todos os lugares) não pode ter seu conteúdo analisado de modo culturalmente específico e reducionista, dada a existência de variadas concepções interculturalmente válidas de identidade (HÄBERLE, 2013, p. 79).

É nesse contexto, convém sublinhar, que aqui se lida com o cluster right da liberdade religiosa, a partir dos dados textuais disponíveis na Constituição Federal, sem descurar dos fatores determinantes da sua constitucionalização: (i) que a institucionalização do fenômeno religioso amiúde degrada-se em coerção e discriminação, tanto em relação aos crentes dissidentes quanto aos não-crentes (freio ao poder); (ii) que a dimensão espiritual é constitutiva da dignidade humana (aspecto identitário) e imprescindível para a autodeterminação pessoal (tutela nuclear da dignidade pessoal); (iii) que a religião é disputada pelo poder político, em busca de lealdade e coesão social. Daí que o Estado democrático de direito regule o tema, a fim de compatibilizar a mais ampla e livre (con) vivência religiosa com os valores constitucionais basilares (igual dignidade e liberdade, pluralismo intercultural, justiça social - que materializam o núcleo duro do programa constitucional). Tudo levando a um conceito amplo de liberdade religiosa e de religião, um âmbito normativo alargado.

No plano objetivo (isto é, para além do direito subjetivo titulado pelas pessoas físicas e pelas confissões religiosas), o multicitado princípio da separação foi desdobrado numa tríade de princípios (cinco), deveres de proteção (três) e garantias institucionais (quatro), numa exploração da multifuncionalidade dos direitos fundamentais. Assim: (a) 
princípio da separação; princípio (de conteúdo e implicações distintas) da não confessionalidade (evitou-se falar em neutralidade); princípio da cooperação; princípio da solidariedade; e princípio da tolerância; (b) dentre os deveres de proteção estatal: a proteção dos indivíduos; a proteção à sociedade civil contra os abusos; e o dever de aperfeiçoamento; (c) entre as garantias institucionais: a liberdade religiosa individual; a liberdade religiosa coletiva; o princípio da igualdade; e a diversidade e o pluralismo religiosos (WEINGARTNER NETO, 2007, p. 317-319). Em tal gradil analítico, não é de descartar eventuais ações afirmativas.

Neste quadro, podem-se trilhar marcos legais, sempre a partir da Constituição Federal, além dos já citados. Selecionam-se alguns: Lei no 9.459 (1997), que criminalizou a injúria racial; Lei no 10.639 (2003), incluiu no currículo oficial da rede de ensino a obrigatoriedade da temática "História e Cultura Afro-Brasileira" - mais que isso, introduziu o art. 79-B na Lei no 9.394/96, estipulando a inclusão no calendário escolar do dia 20 de novembro como "Dia Nacional da Consciência Negra"; Lei no 11.635 (2007), instituiu o Dia Nacional de Combate à Intolerância Religiosa; Lei no 12.288 (2010), plasmou o Estatuto da Igualdade Racial (EIR); e o I Plano Nacional de Desenvolvimento Sustentável dos Povos e Comunidades Tradicionais de Matriz Africana (PCTMA, 2012-2015). No Rio Grande do Sul, aliás, ainda antes da Constituição Federal, a Lei Estadual no 8.352 (1987) já instituíra o dia 20 de novembro como o "Dia Estadual da Consciência Negra". Seguem-se algumas pistas.

O Dia Nacional de Combate à Intolerância Religiosa é 21 de janeiro (também o Dia Mundial da Religião), consta que data de falecimento, no ano de 2000, de Mãe Gilda, dirigente de um terreiro de candomblé em Salvador, por complicações de saúde decorrentes da invasão e depredação que sofreu após reportagem publicada em jornal ligado à Igreja Universal do Reino de Deus que denunciava "macumbeiros charlatães".

O EIR não explicita o campo religioso ao tratar da discriminação racial ou étnico-racial (art. 1ํ, I), mas conceitua no mesmo artigo (inciso VI) ações afirmativas [cuja adoção é prioritária, art. 4º, II] para corrigir desigualdades raciais e promover a igualdade de oportunidades, para reparar distorções durante o processo de formação social do Brasil. Proclama-se ser dever do Estado e da sociedade garantir a todo cidadão 
brasileiro participação na comunidade, "defendendo sua dignidade e seus valores religiosos e culturais" (art. 2º̣). São diretrizes político-jurídicas a inclusão das vítimas de desigualdade étnico-racial, valorizar a igualdade e fortalecer a "identidade nacional brasileira" (art. $3^{\circ}$ ). Quilombos têm o direito a proteger seus manifestos religiosos (art. 18, caput).

Especificamente, o direito à liberdade de consciência e de crença e ao livre exercício dos cultos de matriz africana consagra-se no artigo 24 , com a prática de cultos, celebração de reuniões, fundação e manutenção de lugares reservados [terreiros] para tais fins (I), bem como a celebração de festividades e cerimônias de acordos com os respectivos preceitos (ii), comunicando-se ao Ministério Público, para fins de persecução penal, atitudes e práticas de intolerância religiosa nos meios de comunicação e noutros locais. 0 artigo 26 comanda, ao Poder Público, combate à intolerância com as religiões de matriz africana e à discriminação de seus seguidores, coibindo a utilização dos meios de comunicação para expor pessoas ou grupos ao ódio ou ao desprezo por motivos fundados na religiosidade de matrizes africanas (I). ${ }^{22}$

Quanto ao PCTMA, constitui narrativa na qual os povos tradicionais de matriz africana se reconhecem como "unidades de resistência africana no Brasil" [um reconhecimento específico, para além dos povos indígenas e comunidades quilombolas], destacando os cerca de cinco milhões de escravizados que vieram para o país. Caracteriza-se pela transversalidade das políticas de enfrentamento ao racismo e à discriminação. No Eixo 1 (garantia de direitos) postula-se o reconhecimento de sua contribuição na construção do Brasil e a "valorização da ancestralidade que estabelece vínculos identitários entre o continente Africano e o Brasil" - e o objetivo 3, neste contexto, é combater o racismo institucional. No Eixo 2 (territorialidade e cultura) definem-se territórios tradicionais como os "espaços necessários à reprodução cultural, social, religiosa, ancestral e econômica", a base da organização social e da identidade cultural dos povos e comunidades tradicionais de matriz africana, cuja invisibilidade "se reflete na ausência de levantamentos e dados oficiais sobre essa parcela da população brasileira". ${ }^{23}$

Volte-se a Zumbi. Volte-se a Palmares, ao Quilombo. ${ }^{24}$ 
Zumbi, mais de três séculos depois de morte, está bem vivo e "mergulhado numa guerra", em que se luta "pela memória dos brasileiros. O campo de batalha é o calendário cívico nacional, no qual confrontamse duas datas de alto valor simbólico. (...) A polêmica é menos trivial do que se imagina. Nela estão diferentes visões a respeito da história da escravidão, seus acontecimentos e personagens e também o seu legado para as atuais e futuras gerações" (Grifamos) (GOMES, 2019, p. 421 e 422 , respectivamente). ${ }^{25}$

Nada surpreendente, pois "Personagens, datas e acontecimentos históricos são ferramentas de construção de identidade. Funcionam como âncoras lançadas no passado nas quais procuramos alicerçar valores, convicções, sonhos e aspirações do presente, enquanto preparamos a jornada rumo ao futuro. E, como todos os símbolos, geralmente são mais produtos de edificações imaginárias do que de fatos objetivos e comprovados - o que também os torna alvos de infindáveis investigações e discussões entre os pesquisadores. Palmares e o seu mártir Zumbi são bons exemplos disso". ${ }^{26}$

Sendo assim, tudo desaconselha abordagens históricoessencialistas, que descartam a priori outras possíveis leituras do passado no que se projeta de identidade presente e como projeto de futuro $^{27}$. No caso, não há impedimento, epistemológico, para associar Zumbi, Palmares e quilombos às religiões de matriz africana. ${ }^{28}$ Pelo contrário, há boa literatura a aconselhar tal passo, trilhado, numa escolha que também é política, no exercício de conformação democrática, pelo legislador municipal de Porto Alegre.

Pois, no Brasil, afinal, "contrariando a ladainha que descreve um sistema menos severo - escravizados e escravizadas reagiram mais, mataram seus senhores e feitores, se aquilombaram, suicidaram-se, abortaram, fugiram promoveram insurreições de todo tipo e revoltas dos mais diferentes formatos. Também negociaram seu lugar e condição, lutando para conseguir horas de lazer, recriar seus costumes em terras estranha, cultuar seus deuses e realizar suas práticas, cuidar de suas lavouras, e trataram de preservar suas famílias e filhos" (SCHWARCZ, 2019, p. 29). 
Porto Alegre, a seu turno, também experimentou o específico fenômeno do "impacto urbano da escravidão, entre as décadas finais do século XVIII e a primeira metade do século XIX". 29 O batuque no Rio Grande do Sul é uma das variantes regionais das religiões de matriz africana, cujos saberes, cosmovisões e práticas rituais foram muito diversos e experimentaram contínuas transformações até se configurarem "historicamente através de processos de interação cultural africana bastante complexos, e de modo relacional, com o catolicismo ibérico, as culturas ameríndias e o espiritismo kardecista. Embora essas religiões se apresentem como 'tradicionais' e enraizadas num passado africano remoto, elas são relativamente modernas, boa parte tendo adquirido sua forma padronizada atual só a partir da segunda metade do século XIX" (PARÉS, 2018, p. 377) ${ }^{30}$.

Consabido, desde o período colonial, que "as religiosidades de matriz africana ocuparam uma posição de subalternidade em face da hegemonia do catolicismo". Na ortodoxia da Igreja, tudo não passava de "feitiçaria, idolatria, magia, nunca religião. A perseguição e a discriminação obrigaram os africanos a desenvolver táticas de ocultação que vinham reforçar o secretismo próprio das religiões iniciáticas. 0 sincretismo, ou correspondência entre santos católicos e santos africanos, podia ser uma estratégia de ocultação, ou talvez uma forma de se apropriar, por imitação, do universo espiritual do senhor para, assim, melhor controlá-lo"31.

O movimento negro, neste contexto, "levantou-se contra este projeto de sociedade denunciando e tornando explicito o racismo presente nas relações sociais, bem como passou a orientar suas ações a partir do universo simbólico e vivencial de uma imaginada cosmovisão africana, tendo na religião um espaço privilegiado de resgate de sua identidade. Assim, pôde tornar visíveis os efeitos de poder e a opressão sobre as comunidades religiosas da diáspora africana no Brasil e a consequente falta de direitos relativos ao livre exercício de sua religiosidade" (ARAÚJO, 2018, p. 48) ${ }^{32}$. Agora, exigem "o exercício público de sua religiosidade diferenciada, orientando suas ações não mais sob o disfarce sincrético, mas na exaltação de sua cosmovisão africana, como forma de superação da herança colonialista que impede o livre desenvolvimento de sua religiosidade, [...]" - é dizer, reconhecem a "necessidade de uma postura 


\section{positiva do Estado na preservação do universo simbólico dessas} religiões, que podemos considerar como uma ruptura da laicidade do Estado" (Grifamos) (ARAÚJO, 2018, p. 60 e 73, respectivamente).

Nenhuma surpresa. Em avançado referencial teórico, Boaventura advoga que as "teologias pluralistas e progressistas podem ser uma fonte de energia radical para as lutas contra-hegemônicas dos direitos humanos", o que observou diretamente como participante ativo do Fórum Social Mundial desde 2001, baseando, muitos ativistas, "as suas reivindicações em crenças religiosas ou espiritualidades cristãs, islâmicas, judaicas e indígenas" (SANTOS, 2013, p. 12). 0 critério para distinguir tais teologias das versões fundamentalistas é uma dupla relação: entre razão e revelação; e entre revelação e história. As teologias pluralistas concebem a "revelação como um contributo para a vida pública e a organização política da sociedade, mas aceitam a autonomia de ambos"; também aceitam a separação do Estado e da sociedade civil, e argumentam que "a sociedade civil configura um espaço público não estatal, no qual a religião tem de intervir - através da família, instituições da sociedade civil, organizações não governamentais - com o objetivo de exercer alguma influência sobre o Estado". Quanto às progressistas, fundam-se na distinção entre "religião dos oprimidos e a religião dos opressores e criticam severamente a religião institucional como sendo a religião dos opressores" (SANTOS, 2013, p. 39-40 e 43).

Convivendo o sagrado e o profano, a religioso e o secular, o transcendente e o imanente, direitos humanos, modernidade e teologias políticas geram ampla turbulência entre princípios rivais, "tão reveladora da injustiça socioeconômica como o é da injustiça cognitiva". E Boaventura encontra "um enorme potencial para a tradução intercultural entre os direitos humanos reconstruídos e as teologias políticas progressistas plurais - sejam elas cristãs, islâmicas ou outras" (SANTOS, 2013, p. 90-104).

Num texto seminal, o mesmo Boaventura discorre sobre a construção intercultural da igualdade e da diferença e postula um novo meta-direito intercultural, que deve presidir a articulação pós-colonial e multicultural das políticas de igualdade e de identidade: "temos o direito a ser iguais sempre que diferença nos inferioriza; temos o direito de ser diferentes sempre que a igualdade nos descaracteriza" (SANTOS, 2010, p. 313 e 316). 
Neste contexto, se a mirada pretende-se intercultural, há necessidade de maior conhecimento de outras experiências jurisprudenciais do continente latino-americano, na linha do que preconiza Baldi, no particular com olhos na jurisprudência colombiana que, mercê de um amplo reconhecimento da diversidade cultural, a partir da leitura da Constituição de 1991, vem desenvolvendo o conceito de "igualdade extensiva". Segundo a Corte Constitucional da Colômbia, o princípio da igualdade, na forma do art. 13 da Constituição, implica quatro mandatos: (i) de trato idêntico (destinatários em circunstâncias idênticas); (ii) de trato inteiramente diferenciado (destinatários cujas situações não compartem nenhum elemento em comum); (iii) de trato paritário (situações com similitudes e diferenças); e (iv) de trato diferenciado "a destinatários que se encontrem também em uma posição em parte similar e em parte diversa, mas em cujo caso as diferenças sejam mais relevantes que as similitudes". Assim, prossegue Baldi, "tem-se entendido que a 'omissão legislativa relativa de caráter discriminatório', produzida pela não inclusão de todos supostamente iguais aos regulados pela lei, significa, no geral, que tais disposições não são inconstitucionais pelo que, em si, dispõem, mas sim 'por não fazer extensivas essas disposições a outros supostos de fato iguais aos regulados', fazendo com que a Corte profira uma sentença integradora, "que faz extensivos os efeitos da regulação legal aos fatos não contemplados pela lei” (Destacamos) (BALDI, 2013).

Como o capítulo 2 do Relatório do Desenvolvimento Humano Liberdade Cultural num Mundo Diversificado mostra, "muitas minorias religiosas de todo o mundo sofrem várias formas de exclusão. Nalguns casos, isto deve-se à discriminação explícita de uma minoria religiosa - problema muito comum em países não seculares, onde o Estado tem a missão de apoiar e promover uma religião oficial. Mas noutros casos, a exclusão pode ser menos directa e talvez até involuntária, como quando o calendário público não reconhece feriados religiosos de uma minoria (...)" (gizamos) (FUKUDA-PARR, 2004). Na mesma publicação, a Figura 2.5, inserida em item que trata da EXCLUSÃO POLITICA, ECONOMICA E SOCIAL BASEADA NA IDENTIDADE CULTURAL, refere como os Feriados nacionais são um meio importante de reconhecer - ou ignorar - identidades culturais, baseando-se nas diversas religiões 
refletidas nos feriados nacionais em França, Índia e Estados Unidos ${ }^{33}$ (FUKUDA-PARR, 2004, p. 35 e 36).

\section{CONSIDERAÇÕES FINAIS}

O que se percebe, em visão panorâmica, é uma realidade turbulenta no cenário religioso, negociando-se, em tensão, alterações na prática social marcada pela escravidão, e, na chave ambígua de nossa cidadania inconclusa, propostas pluralistas e progressistas, dentre as quais celebrar o 20 de novembro modo interseccional, como energia emancipatória decorrente da consciência negra e da difusão das religiosidades de matriz africana.

Para além das fundamentais modificações materiais que algumas das ações afirmativas visando à superação do racismo oportunizam - e também se trata disso, visibilizar uma prática minoritária que a hegemonia teima em obnubilar -, estamos testemunhando disputas simbólicas.

Immanuel Wallerstein perguntava, sobre bandeiras e outros símbolos: será que eles importam? Da bandeira confederada de conotações racistas na Carolina do Sul, passando pela Ucrânia, Rússia, Venezuela, França, Espanha e Índia, afirma que sim, que nunca se trata de território neutro, e que as pessoas sabem que eles importam, tanto porque criam atitudes como porque atitudes criam ou refletem-se em símbolos. A par da relevância na socialização das crianças, se o racismo não será menos real - no curto prazo - com a alteração simbólica, no longo prazo é parte indispensável na luta por um mundo no qual se vive e que se espera construir (WALLERSTEIN, 2015).

E se o feriado de Zumbi puder ser narrado de outro jeito? E se depois de bater na trave, a bola entrou no gol? Naquele então, as felicidades vão para além do quase, possibilitando ao coro das vozes das religiosidades de matriz africana ser ouvido pelas arquibancadas do país - a vivência delas a falar, não suas cicatrizes. Um imaginário, simbólico, para dialogar com a esperança de Hans Küng (KÜNG, 2004, p. 41-42), quanto à contribuição africana para uma ética mundial neste novo milênio: com seu forte senso de comunidade e solidariedade; com a alta apreciação dos seus valores 
e critérios tradicionais; com sua visão holística do mundo e do homem, onde há lugar para jovens e velhos e onde a tradição e o progresso andam de mãos dadas.

Para encerrar, voltemos novamente os olhares para a dignidade da pessoa humana, lembrando-nos que a realização de tal projeto pressupõe, também, como bem refere Peter Häberle, por um projeto pedagógico do Estado constitucional, o da dignidade humana para cada um e para o próximo, como tolerância e solidariedade (HÄBERLE, 2013, p. 88).

\section{NOTAS}

1 Ainda expresso em muitas discussões acerca das políticas afirmativas, de fundo racial, emblemática a Lei no 12.990/2014, que reserva 20\% das vagas em concursos públicos federais a candidatos negros (autodeclarados pretos ou pardos), mediada, no âmbito do Poder Judiciário, pela Resolução no 203 (23/6/2015) do Conselho Nacional de Justiça, abarcando inclusive o ingresso na magistratura. A resolução refere tanto a decisão do STF na ADPF 186/DF quanto os resultados do Primeiro Censo do PJ, realizado pelo próprio CNJ.

2 "Durante décadas, os objetos ficaram expostos no Museu da Polícia Civil ao lado de armas de fogo, bandeiras nazistas e outras apreensões históricas ligadas ao crime no Rio. A campanha Liberte Nosso Sagrado reivindica a participação de lideranças religiosas na definição de como as peças poderão e deverão ser expostas e pede a mudança do nome da coleção para coleção do Sagrado Afro-brasileiro, rejeitando a pecha de 'magia negra'”. A ialorixá ainda tem muita esperança de recuperar as coisas e pergunta: "Por que o nosso sagrado tem que estar no Museu da Polícia? Nós não praticamos nenhum crime. Não é crime a gente ser de orixá”.

3 Para maiores detalhes, WEINGARTNER NETO, 2019.

4 O julgamento iniciou em agosto de 2018 (data dos votos citados) e concluiu-se em 28 de março de 2019, negado provimento ao RE, vencidos parcialmente os Ministros Marco Aurélio (Rel.), Alexandre de Moraes e Gilmar Mendes, que admitiam a constitucionalidade da lei dando interpretação conforme. A tese produzida foi a seguinte: "É constitucional a lei de proteção animal que, a fim de resguardar a liberdade religiosa, permite o sacrifício ritual de animais em cultos de religiões de matriz africana" - grifos nossos.

5 “Em média, a Igreja Católica perdeu 465 fiéis por dia entre 2000 e 2010. Os evangélicos ganharam 4.383 novos fiéis por dia no mesmo período”, sendo as denominações pentecostais as que mais crescem, cfe. VALOR Econômico, p. 5.

6 Outras religiões alcançaram 2\%, sem religião 7\% e ateus 1\%, cf. Religião P0813684, 06 e 07/06/2013, DATAFOLHA, 2013.

7 A mencionada nota pública decorreu da 6ª Reunião Ordinária (04/4/2016) do aludido comitê - COMITÊ, 2016.

8 “A coluna 360 Graus de sábado publicou texto intitulado 'Eles são o futuro do Brasil'. Na cara do Mickey Mouse, personagem de Walt Disney, aparece a foto de 17 crianças - meninos e meninas com menos de cinco anos. Eles têm um ponto em comum: são brancos. Não há nenhum negro, indígena ou oriental. Leitores protestaram contra a hegemonia branca. Com razão. Foi um erro gravíssimo! O Brasil é um país miscigenado em que convivem pessoas de diferentes origens, diferentes credos, diferentes tendências políticas. 0 tabuleiro de raças, cores e culturas é que faz o Brasil" (VISÃo, 2019).

9 E conclui: "Ainda que os negros fossem uma minoria, merecíamos ser bem representados na mídia. Sendo maioria, é uma questão também de democracia. 0 destino da mídia está atrelado à atenção e à importância que (não) dá a mais de 55\% da população brasileira". 
10 O quadro é de difícil precisão, mas GOMES (2019) refere que, em 2018, apenas 1.047 municípios (de um total de 5.561) optaram pelo feriado (2019, p. 422), sendo que em alguns estados nenhuma cidade o adotou (RN, CE, PE, PA, RO). Estima-se, noutro informe, que o feriado da Consciência Negra atinja 10\% do Brasil. Para ilustrar, em SP é feriado em 102 municípios, incluindo a Capital; dos estados da Região Sul, no RS não é feriado em nenhuma cidade; em SC, apenas na Capital; e no PR, em apenas duas cidades - cfe. SANDIN, 2018.

11 Cfe. Parecer aprovado à unanimidade na Comissão de Cultura em 1ำ/7/2015: "A medida, sem dúvida, propiciará atividades de valorização da cultura negra em âmbito nacional e despertará a conscientização da população brasileira, visando o combate ao preconceito racial e à disseminação da herança cultural negra. Afinal, passados quase 130 anos da Lei Áurea, as consequências nefastas do que se prestou a abolir ainda são sentidas por parcela expressiva de nossa população, seja pelo preconceito, seja pela falta de condições igualitárias e ações afirmativas para conferir ao povo, antes escravizado, um ambiente propício a sua reafirmação como indivíduos livres e passíveis de direitos. Importante ressaltar que esta Comissão já se debruçou sobre o tema quando da aprovação do PL no 6.787, de 2013 (...) apesar de aprovada em duas Comissões, a matéria foi arquivada ao final da 54a Legislatura.... Houve requerimento para que o projeto fosse também apreciado pela Comissão de Desenvolvimento Econômico, Indústria, Comércio e Serviços.

12 Citou números da Confederação Nacional do Comércio, estimando prejuízo de 15,5 bilhões ao comércio em 2015 (3\% a 4\% do faturamento global das empresas do segmento). Acresceu que o feriado nacional ensejaria aos municípios que já adotassem a data como feriado local a "instituição de um novo feriado municipal", o que poderia ocasionar a "paralisação da economia por mais um dia nessas cidades" - francamente, no ponto, não se atina como. Interessante que há registro de voto em separado, do Deputado Helder Salomão, que referiu anterior parecer do Deputado Mauro Pereira, de 20/5/2016, pela "aprovação na forma de um substitutivo semelhante ao da Comissão de Cultura". Antes, porém, que fosse discutido ou deliberado, "o relator alterou seu parecer e apresentou voto pela rejeição da proposição em 22 de junho de 2016".

13 Registrou o Ministro Relator: "O cerne do diploma legislativo sob ataque é celebrar valores históricos e culturais reputados relevantes pelo legislador fluminense. A importância histórica e cultural da data celebrada como feriado (aliás também em muitos outros Estados-Membros, tais como Alagoas, Amapá, Mato Grosso e Rio Grande do Sul [sic], e em inúmeros Municípios do País) sobrepõe-se aos efeitos secundários da norma verificados no campo econômico. Assim, não obstante a CNC se declare vocacionada, entre outras finalidades, a representar os direitos e interesses do comércio brasileiro de bens, de serviços e de turismo, e a defender a livre iniciativa, a economia de mercado, a liberdade para exercer o comércio de bens de serviços e de turismo, e a ética no desempenho da atividade profissional (art. 1ํㅡ, incisos I, VII e VIII de seu Estatuto Social, fls. 24), tal proclamação não a habilita a instaurar a jurisdição constitucional concentrada para opor-se a leis de caráter geral que versem sobre conteúdo de aspecto histórico-cultural, ainda que, eventualmente, referido mecanismo possa ensejar, indiretamente, em impactos nas relações econômicas e empregatícias de seus associados. Fosse isso possível, estar-se-ia a outorgar à CNC representatividade transcendental aos interesses de seus filiados, bastante para legitimá-la a intermediar, junto a esta Suprema Corte, uma miríade de interesses difusos tutelados pela Constituição Federal, com absoluta sublimação do âmbito corporativo em que se insere a requerente, elastério que certamente não condiz com a mensagem normativa do art. 103, IX, da Constituição Federal, na interpretação que lhe é conferida por este Supremo Tribunal Federal" - grifamos.

14 PRECEDENTES SOBRE O MESMO FERIADO DECRETADO NOS MUNICÍPIOS DE PELOTAS E DE ALVORADA (ADINS №S 70007645443 E 70007645369 ). Rel. Des. João Carlos Branco Cardoso.

150 projeto é de 21/11/2013. 0 parecer prévio da Procuradoria da Casa Legislativa sinalava, em 06/12/2013, inclusive citando a decisão anterior do TJRS, o óbice jurídico. A Comissão de Constituição e Justiça, no "aspecto da legalidade estrita", em face do "bloqueio de competência" concluiu, em $05 / 3 / 2014$, pela inviabilidade de tramitação do projeto. Houve voto em separado (Ver. Márcio Bins Ely), mencionando mudança do entendimento pelos tribunais brasileiros "em centenas de cidades que adotaram o 20 de novembro como feriado municipal com base em legislações estaduais e municipais" (anexou lista das quase 500 cidades, à época). 0 projeto, em 
análise de mérito, e não jurídica, foi aprovado pela Comissão de Educação, Cultura, Esporte e Juventude, em 20/8/2014. Na sequência, em 22/10/2014, a Comissão de Defesa do Consumidor, Direitos Humanos e Segurança Urbana, pese reconhecer o conteúdo meritório, também rejeitou o projeto citando a anterior decisão do TJRS.

16 A tônica da citada exposição de motivos continua a ser a reflexão sobre o combate ao racismo, referindo o novo ambiente institucional, com ações afirmativas de reparação social, como o sistema de cotas nas universidades brasileiras e a própria assinatura do "Pacto Gaúcho pelo fim do Racismo Institucional" pelo Chefe do Poder Judiciário, além da possibilidade do TJRS instituir cotas raciais nos concursos públicos para a magistratura estadual [o que, de fato, ocorreu]. Explícita, não havia menção à questão da religiosidade, salvo no texto proposto para o dispositivo, consagrando o 20 de novembro como feriado fixo, "Dia da Consciência Negra e da Difusão da Religiosidade” - aliás, houve emendas, rejeitadas, para tornar o feriado móvel, deslocando-o para o domingo mais próximo da data. Em 17/6/2015, as Comissões de Constituição e Justiça; Urbanização, Transporte e Habitação; Educação, Cultura, Esporte e Juventude; e Defesa do Consumidor, Direitos Humanos e Segurança Urbana, aprovaram, conjuntamente, o projeto.

17 Relator Luiz Felipe Brasil Santos, julgada procedente, pelo Órgão Especial do TJRS, por maioria, em 07/11/2016. Também constou da ementa: "Não se desconhece a decisão do STF, no julgamento do Recurso Extraordinário n. 251.470 - Rio de Janeiro. Ocorre, em primeiro lugar, que tal decisão foi no âmbito de um recurso extraordinário, que resultou em extinção do feito sem julgamento de mérito. Por isso, em atenção ao art. 489, § 1ํㅡ, inc. VI, do CPC, afirma-se não existir qualquer violação a esse precedente da Corte Maior. Também não há violação ao art. 927, inc. I, do CPC, porque, além de não haver decisão de mérito naquele precedente, tratou-se lá de um Recurso Extraordinário, e não de uma decisão em sede de controle concentrado de constitucionalidade, como exige o dispositivo em foco" - votaram 23 dos 24 membros do Órgão Especial (um estava impedido), vencidos seis Desembargadores (quatro votaram pelo improcedência e dois extinguiam a ação direta de inconstitucionalidade) - destacamos.

18 E se não for feriado religioso, pergunta ao cabo o Des. Rui Portanova? Ainda assim, o precedente do STF enfrentou um feriado municipal que não se apresentava com o tal caráter religioso e a solução foi manter o feriado (homenagem a Zumbi pela "atuação cívica revelada pelo personagem que acabou por integrar a História no panteão que a Pátria deve cultuar"), forte na competência para legislar sobre assunto de interesse local. Cita, em reforço, Leonardo Tricot Saldanha, para concluir que "nada impede que os municípios decretem feriados baseados no interesse local".

19 O Des. Armínio, ainda, asseverou que Federação tem sistema, não é desordem, é preciso haver um mínimo de disciplina, o que fez a lei federal, "porque alguém tem que definir qual vai ser o critério quanto à competência para dispor sobre feriados". Quanto ao bloqueio de competência: "Aliás, quando o legislador municipal invade aquilo que é regrado pela lei federal, temos aqui reiteradamente tida por inconstitucional a lei municipal por ofender o princípio de bloqueio de competência. Também aqui, novamente, tem que ser feita uma colocação: se o art. 8o, CE/89, se o bloqueio de competência não vale aqui, não pode valer mais em nenhum outro caso neste Órgão Especial. E se tem afirmado que 'os Municípios não podem, no exercício de sua competência legislativa suplementar ou completiva, restringir as regras gerais estabelecidas em lei federal sobre o mesmo assunto. Destarte, forçoso concluir pela inconstitucionalidade da norma, em face da tese do bloqueio de competência' (Ação Direta no 70051070357 deste Órgão Especial)".

20 WEINGARTNER NETO, 2007, p. 96-108 aborda as dificuldades tanto das definições objetivas quanto do critério funcional, defendendo as possibilidades de um conceito tipológico: o ponto de partida da conceituação em tela leva em conta os "elementos geralmente considerados típicos do fenômeno religioso", suas parecenças de família (Wittgenstein): visão global do mundo; apelo a autoridades e conteúdos veritativos de origem e valor extra-racional; consciência subjetiva da existência de um poder sobrenatural ou transcendente etc. - papel muito relevante deve ser conferido à noção de heteronomia, vale dizer, ao fato de que os imperativos religiosos são entendidos pelo sujeito "não como emanações endógenas da sua própria consciência, mas sim como imposições inelutáveis, de natureza objetiva e exógena”. (...) Importa, é claro, a similitude/contraste que o fenômeno a qualificar (a hipótese religiosa) assuma em face das "várias religiões mais conhecidas". Mas, se pode haver relação direta de religiosidade, consoante maior 
aproximação com o standard - a significar valoração do fenômeno como religioso e tratamento estatal análogo ao dispensado às confissões religiosas mais comuns -, a proposição inversa é mais duvidosa, não se podendo inferir relação de desvalorização religiosa ao constatar contraste com o padrão utilizado. Daí que a doutrina advirta para o caráter "meramente indicativo, não decisivo, dos critérios dicotômicos tradicionais" (imanente/transcendente, natural/sobrenatural, sagrado/profano, razão/revelação - como a referência à "visão global do mundo" pode ceder, nalguns casos, à referência a "aspectos parcelares da vida"), bem como de elementos externos ao fenômeno religioso Pode-se, sem dúvida, tentar aprimorar o elenco de "parecenças de família", na exploração intercultural das raízes mítico-simbólicas do "misterioso e imenso" mundo das religiões, distinguíveis pelo menos três grandes correntes: as religiões originárias da Índia (os tipos convocantes são o hinduísmo e o budismo - figura-chave, o místico); as originárias da China (confucionismo e taoísmo - o sábio); e aquelas do Oriente Médio (judaísmo, cristianismo e islamismo - o profeta) - sem descurar o substrato das religiões tribais (dos aborígenes e da África, o "terreno onde todas as religiões estão enraizadas) - WEINGARTNER NETO, 2007, p. 102-103 e 106-107).

21 Cf. WEINGARTNER NETO, 2007, p. 50-54 (fundamentalismo, entre a crença e a ação) e WEINGARTNER NETO, 2007, p. 243-51 (proposta de tratamento seletivo entre fundamentalismo-crença e fundamentalismo militante, tendo os valores aglutinantes como paradigma regulatório - iguais em dignidade e liberdade, justiça social e pluralismo, uma espécie de núcleo duro do programa constitucional); para a inclusividade, WEINGARTNER NETO, 2007, p. 46-50. A relação entre dignidade humana, direitos fundamentais e democracia, esta como consequência organizatória daqueles é particularmente desenvolvida em HÄBERLE, 2013, p. 83-88.

22 Neste particular, ilustrativa a decisão da Sexta Turma do TRF da 3a Região (Apelação Cível nº 0034549-1120044036100), ao negar as apelações da Rádio e Televisão Record S/A e Rede Mulher de Televisão Ltda e consignar: "Chamadas televisivas. POSSIBILIDADE. DIREITO DE RESPOSTA COLETIVO. GARANTIA À LIBERDADE DE CONSCIÊNCIA E DE CRENÇA. SERVIÇO PÚBLICO DE RADIODIFUSÃO. SUPREMACIA DO INTERESSE PÚBLICO. PROGRAMA TELEVISIVO. CARÁTER PEJORATIVO E DISCRIMINATÓRIO. DESONRA. GRUPO RELIGIOSO OU CULTURAL. CONFIGURAÇÃO. (...) 11. Não restam dúvidas de que chamar 'mães e pais de santo' de 'mães e pais de encosto' tem um nítido caráter pejorativo e discriminatório, sendo fundamental o respeito e a preservação das manifestações culturais dos afrodescendentes, por fazerem parte do processo civilizatório nacional e merecerem, por essa razão, a tutela constitucional dispensada pelo art. 215, 'caput' e $\S 1^{\circ}$, da Constituição da República. 12. 0 menosprezo às religiões afro-brasileiras, constrangendo os seus adeptos imputando-lhes expressões ofensivas, configura verdadeiro desrespeito à liberdade de crença, bem como à dignidade da pessoa humana".

23 Dados parciais já levantaram 7.582 casas de tradição de matriz africana; outra pesquisa revela a intensa relação que os territórios tradicionais mantêm com a comunidade do seu entorno (81,6\% das casas desenvolvem atividades comunitárias, das quais 95\% distribuem alimentos, sendo que $45 \%$ diariamente).

24 Segundo GOMES, 2019 "As incertezas a respeito de Palmares remontam a sua origem. Acredita-se que tenha começado com a fuga de algumas dezenas de escravos de um único engenho no sul de Pernambuco no final do século XVI. (...) Outro enigma no estudo de Palmares diz respeito aos seus costumes e à procedência de seus habitantes. (...) 0 mais provável é que sua composição tivesse mudado ao longo dos anos, de acordo com as regiões da África que mais forneciam escravos para o Brasil em determinados períodos" (GOMES, 2019, p. 408). Pese notícias de "rituais religiosos ao estilo tradicional africano", também, "numa de suas expedições militares, os portugueses encontraram uma Igreja Católica", a sugerir que "Palmares foi se transformando e se adaptava às crenças e aos costumes que sofreram todos os escravos africanos e seus descendentes que chegaram ao Brasil" (GOMES, 2019, p. 409).

25 A disputa, carregada de aspectos ideológicos, continua, como se vê em ZANINI, 2019: “Conservadores consideram Zumbi, no mínimo, uma figura do qual se sabe muito pouco, e que portanto não merece o título de herói nacional. Alguns o veem como um personagem violento, que criou uma corte em torno de si e tolerava algumas formas de escravidão. Mais adequado, diz a direita, é celebrar o 13 de maio, data da Abolição da escravatura pela Princesa Isabel, em 1888. Ou 
relembrar personagens históricos como Luís Gama, advogado negro que foi escravo e se tornou um dos grandes abolicionistas brasileiros. Por trás da discussão histórica, há a sempre presente polarização do debate público. A direita entende que o 20 de novembro é utilizado pela esquerda em um contexto mais amplo, o dos movimentos identitários, que se traduzem em políticas como cotas raciais nas universidades".

26 “(...) o desfecho dessa guerra em torno do calendário cívico, longe de acabar, depende muito da capacidade da sociedade brasileira de se pôr de acordo a respeito dos significados em torno de Zumbi. Quem teria sido ele? Por mais óbvia que pareça, a pergunta carece de respostas consistentes. Num dos livros mais instigantes já publicados sobre o tema, os historiadores Jean Marcel Carvalho França e Ricardo Alexandre Ferreira, professores da Universidade Estadual Paulista Júlio Mesquita Filho, a Unesp, campus de Franca, afirmam que traçar a biografia de Zumbi seria hoje uma tarefa impossível. (...) Sua história permanece repleta de sombras, o que impediria que se tivesse uma visão mais nítida sobre ele. Na ausência de depoimentos pessoais ou documentos escritos por ele ou seus comandados, sobraria apenas o mito, lenta e laboriosamente construído ao longo dos séculos por historiadores, religiosos, militares, romancistas e, mais recentemente, militantes políticos. 0 resultado é a edificação de um Zumbi que, na verdade, nunca existiu. Está nos sonhos, na imaginação e nas convicções de cada pessoa e cada geração de brasileiros que sobre ele se debruçaram na vã tentativa de desvendar-lhe o mistério. Estudar Zumbi, dessa forma, permitiria conhecer mais o Brasil e sua complicada relação com o passado escravagista do que o próprio personagem" - GOMES, 2019, p. 422-424 - gizamos.

27 Em sentido confluente: "História e memória são formas de entendimento do passado que nem sempre se confundem ou mesmo se complementam. A história não só carrega consigo algumas lacunas e incompreensões frente ao passado, como se comporta, muitas vezes, qual campo de embates, de desavenças e disputas. Por isso ela é, por definição, inconclusa. Já a memória traz invariavelmente para o centro da análise uma dimensão subjetiva ao traduzir o passado na primeira pessoa e a ele devotar uma determinada lembrança: daquele que produz. Assim, ela recupera o 'presente do passado' e faz com que o passado vire também presente" - SCHWARCZ, 2019, p. 20.

28 Schwarcz e Starling apontam, no período entre os anos 1820 e 1840, que os movimentos políticos tinham cor. O Levante dos Malês (1835), talvez a maior rebelião escrava ocorrida no Brasil (precedida por revoltas em 1807 e 1814), "foi igualmente uma luta religiosa e étnica”, neste caso em torno da religiosidade islâmica; em 1826, um grupo de escravos refugiados no quilombo do Urubu, na periferia de Salvador, também rebelou-se - "na primeira metade do século XIX, quilombos e práticas de candomblé se misturaram"; no Urubu, usou-se pela primeira vez a palavra "candomblé", num contexto de rebelião, "para nomear o refúgio dos escravos rebelados. (...) na Bahia, no século XIX, a religião havia se transformado em linguagem política para os escravos" (SCHWARCZ; STARLING, 2015, p. 257 e 254-255).

29 "Não são poucas as investigações que têm sublinhado a importância da cultura urbana escrava: os setores de serviços que contavam com mão de obra escrava, os números de escravos de ganho, os cativos alugados, os escravos domésticos, bem como os desdobramentos no que se refere às práticas públicas, à vigilância e à política de rumores e boatos. Estamos no referindo, pois, não só ao medo constante de revoltas, como à especificidade da escravidão urbana em termos da cultura material e social" (SCHWARCZ, GOMES, 2018, p. 26). Adiante (SCHWARCZ, GOMES, 2018, p. 37): "Surgiriam inúmeras associações (muitas das quais sociedades dançantes, carnavalescas, bandas de música e aquelas mutualistas de operários) abolicionistas em cidades grandes e pequenas das províncias de Pernambuco, Grão-Pará, Maranhão, Bahia e Rio Grande”.

30 Mais precisamente: "Da mesma maneira que no Brasil, no continente africano as crenças e as práticas religiosas raramente constituíram um sistema homogêneo e estável, bem como careciam de um panteão fixo. Ao contrário, sempre sofreram contínuos processos de revisão, incluindo elementos novos e excluindo outros. Apesar de sua diversidade cultural, os africanos compartilhavam algumas crenças ou 'orientações cognitivas'. A religiões autóctones africanas não possuem um dogma ou doutrina; ninguém prescreve aquilo em que uma pessoa deve acreditar; e a afiliação a elas se baseia, sobretudo, na participação ritual, mediada pela experiência corporal. O caráter não dogmático e a orientação para ação, combinados com a flexibilidade para integrar 
elementos alheios e reinterpretá-los a partir de velhos padrões, resultaram num pluralismo religioso de extraordinário ecletismo. Tal combinação de fatores foi talvez a principal continuidade cultural que os africanos trouxeram do seu continente e que permitiu a "síntese criativa" ocorrida na diáspora. Nesse sentido, as religiões africanas e afro-americanas não são tradicionais; isso, se "tradicional" implicar ausência de mudança e movimento" - PARÉS, 2018, p. 378-379 - destacamos.

31 "A demonização por parte da igreja foi seguida da criminalização pelos códigos penais, da patologização pelos médicos e da denúncia pelos jornalistas". Numa sociedade escravocrata em que a população africana não tinha espaço político, a religião acabou se convertendo no "poder dos fracos". Os terreiros, como as irmandades católicas, promoviam formas de associativismo negro com capacidade de mobilização. Não por acaso, na Bahia da primeira metade do século XIX, os candomblés estiveram na origem de várias revoltas escravas. Além dessa possível dinâmica de confrontação, o terreiro recriava e perpetuava cosmovisões, saberes e hábitos que desafiavam os pressupostos da sociedade dominante. (...) Mas o terreiro não era só um 'refúgio' contra a escravidão ou um espaço alternativo de reparação e de identidade negra pan-africana. Para o seu sucesso reprodutivo, precisava de certa abertura social de negociação e alianças, muitas vezes travadas através do serviço religioso. Hoje ele mudou muito, porém persiste no campo religioso afro-brasileiro a tensão conflituosa entre os discursos de resistência cultural, a valorização seletiva do Estado e a intolerância que vêm de um novo fundamentalismo cristão" - PARÉS, 2018, p. 382-3.

32 Há uma mudança de trajetória: "A emergência do movimento negro contemporâneo possibilitou a inserção das demandas por direitos dessas religiões na esfera pública, pois, ao pautar a necessidade de defesa e promoção da cultura negra, a luta do povo de santo é deslocada da simples resistência para uma política de reconhecimento de direitos" (ARAÚJ0, 2018, p. 54).

33 Os dados de 2003 e 2004 mostram claramente a sobrerrepresentação cristã em França e Estados Unidos e a gestão mais plural do espaço público indiano.

\section{REFERÊNCIAS BIBLIOGRÁFICAS}

ARAÚJO. Maurício Azevedo de. Entrando em cena, reescrevendo o roteiro e instituindo direitos: a luta por reconhecimento das comunidades religiosas de matriz africana. In: HEIM, Bruno Barbosa; ARAÚJO, Maurício Azevedo de; HOSHINO, Thiago de Azevedo Pinheiro (Org.). Direitos dos povos de terreiro. Salvador: EDUNEB, 2018.

BALDI, César Augusto. A renovação do direito agrário e os quilombos: identidade, território e direitos culturais. Revista da Faculdade de Direito da UFG, v. 37, n. 2, 2013.

GOMES, Laurentino. Escravidão: do primeiro leilão de cativos em Portugal à morte de Zumbi dos Palmares. 1. ed. Rio de Janeiro: Globo Livros, 2019. v. 1.

HÄBERLE, Peter. A dignidade humana como fundamento da comunidade estatal. In: SARLET, Ingo Wolfgang (Org.). Dimensões da Dignidade. Ensaios de Filosofia e 
de Direito Constitucional. 2. ed. Tradução: Ingo Wolfgang Sarlet e Pedro Aleixo. Porto Alegre: Livraria do Advogado, 2013.

DATAFOLHA. Fatia de católicos no Brasil é a menor em duas décadas, 27 de março de 2013. Disponível em: http://datafolha.folha.uol.com.br/ opiniaopublica/2013/07/1314857-fatia-de-catolicos-e-a-menor-em-duasdecadas.shtml. Acesso em: 18 set. 2018.

COMITÊ Nacional de Respeito à Diversidade Religiosa divulga nota pública contra preconceito, discriminação e violência, abril de 2016. Disponível em: http://www.sdh.gov.br/noticias/2016/abril/comite-nacional-de-respeito-adiversidade-religiosa-divulga-nota-publica-contra-preconceito-discriminacaoe-violencia. Acesso em: 25 fev. 2017

SANDIN, Caio. Consciência negra é feriado em 10\% do Brasil. Veja onde. R7 Planalto, 19 de novembro de 2018. Disponível em: https://noticias.r7.com/ prisma/r7-planalto/consciencia-negra-e-feriado-em-10-do-brasil-vejaonde-26042019. Acesso em: 11 nov. 2019.

ZANINI, Fabio. Direita rejeita Zumbi como símbolo negro e exalta abolicionistas. Saída pela direita, Folha de São Paulo, colunas e blogs, 19 de novembro de 2019. Disponível em: https://saidapeladireita.blogfolha.uol.com.br/2019/11/19/ direita-rejeita-zumbi-como-simbolo-negro-e-exalta-abolicionistas/. Acesso em: 19 nov. 2019.

VISÃO do Correio: Erramos. Correio Braziliense, 15 de outubro de 2019. Disponível em: https://www.correiobraziliense.com.br/app/noticia/ opiniao/2019/10/15/internas_opiniao,797564/visao-do-correio-erramos. shtml. Acesso em: 06 nov. 2019.

LIMA, Flavia. Ecos que ainda vêm da casa-grande. Destino da imprensa está atrelado à importância que dá a $56 \%$ da população. Folha de São Paulo, colunas e blogs, 2019. Disponível em: https://www1.folha.uol.com.br/colunas/flavialima-ombudsman/2019/10/ecos-que-ainda-vem-da-casa-grande.shtml. Acesso em: 06 nov. 2019.

CARNEIRO, Julia Dias. A luta para tirar itens de umbanda e candomblé do Museu da Polícia Instituição no Rio de Janeiro os confiscou há mais de um século. $B B C$ News Brasil, Rio de Janeiro, 20 de agosto de 2019. Disponível em: https://www1. 
folha.uol.com.br/ilustrada/2019/08/a-luta-para-tirar-itens-de-umbanda-ecandomble-do-museu-da-policia.shtml. Acesso em: 11 de novembro de 2019.

KÜNG, Hans. Religiões do mundo: em busca dos pontos comuns. Campinas, SP: Verus, 2004.

LEITE, Fábio Carvalho. Estado e religião: a liberdade religiosa no Brasil. Curitiba: Juruá, 2014.

PARÉS, Luis Nicolau. Religiosidades. In: SCHWARCZ, Lília Moritz; GOMES, Flávio dos Santos (Org.). Dicionário da escravidão e liberdade: 50 textos críticos. 1. edição. São Paulo: Companhia das Letras, 2018.

PIOVESAN, Flávia. Estado laico, intolerância e diversidade religiosa no Brasil: pesquisas, reflexões e debates. Ministério dos Direitos Humanos. Secretaria Nacional de Cidadania, 2018.

FUKUDA-PARR, Sakiko (Dir.). Relatório do Desenvolvimento Humano. A liberdade cultural num mundo diversificado. Tradução: José Freitas e Silva. Programa das Nações Unidas para o Desenvolvimento - PNUD/ONU, 2004. Disponível em: http://hdr.undp.org/sites/default/files/hdr2004-portuguese.pdf. Acesso em: 12 nov. 2019.

FONSECA, Alexandre Brasil; ADAD, Clara Jane Costa (Org.). Relatório sobre intolerância e violência religiosa no Brasil (2011-2015): resultados preliminares. Ministério das Mulheres, da Igualdade Racial, da Juventude e dos Direitos Humanos. Brasília: Secretaria Especial de Direitos Humanos, 2016. Disponível em: http://www.direito.mppr.mp.br/arquivos/File/RelatorioRIVIR.pdf. Acesso em: 18 set. 2018.

SANTOS, Boaventura de Sousa. A gramática do tempo: para uma nova cultura política. 3. ed. São Paulo: Cortez, 2010.

SANTOS, Boaventura de Sousa. E se deus fosse um ativista de direitos humanos. São Paulo: Cortez, 2013.

SCHWARCZ, Lilia Moritz. Sobre o autoritarismo brasileiro. 1. ed. São Paulo: Companhia das Letras, 2019. 
SCHWARCZ, Lília Moritz; GOMES, Flávio dos Santos. Introdução. In: SCHWARCZ, Lília Moritz; GOMES, Flávio dos Santos (Org.). Dicionário da escravidão e liberdade: 50 textos críticos. 1. ed. São Paulo: Companhia das Letras, 2018.

SCHWARCZ, Lilia Moritz; STARLING, Heloisa Murgel. Brasil: uma biografia. São Paulo: Companhia das Letras, 2015.

VALOR Econômico, Eu \& Fim de Semana, 09 de outubro de 2015.

WALLERSTEIN, Immanuel. Flags and other symbols: do they matter? Commentary n. 405, july 15, 2015.

WEINGARTNER NETO, Jayme. Arena do sagrado e o proselitismo religioso na palavra do STF. Revista Eletrônica Direito e Sociedade, Canoas, v. 7, n. 1, 2019.

WEINGARTNER NETO, Jayme. Liberdade Religiosa na Constituição: pluralismo, fundamentalismo, crenças e cultos. Porto Alegre: Livraria do Advogado, 2007.

Recebido em: 01-07-2020

Aprovado em: 26-10-2020 


\section{Ingo Wolfgang Sarlet}

Doutor em Direito pela Universidade de Munique (1997). Estágio Pós-Doutoral (bolsa DAAD) na Universidade de Munique (2005). Estudos em nível de PósDoutorado como bolsista do Instituto Max-Planck de Direito Social e Política Social (2001-2003 e 2005), Munique e no Georgetown Law-Center. (2004). Professor Titular e Coordenador do Programa de Pós-Graduação em Direito da PUCRS. Coordenador do Grupo de Estudos em Direitos FUndamentais (CNPQPUCRS). Coordenador do DINTER PUCRS-Faculdade Católica de Rondônia, Porto Velho, e do MINTER PUCRS-Centro Universitário Dom Bosco, São Luís, Maranhão. Foi pesquisador visitante na Harvard Law School (2008) e como bolsista (fellow) do Stellenbosch Institute for Advanced Studies, África do Sul, bem como bolsista do Instituto-Max-Planck de Direito Social e Política Social, Munique (2019 e 2020). Pesquisador Visitante do Instituto Max-Planck de Direito Privado Estrangeiro e Internacional de Hamburgo, Alemanha, 2017 com bolsa do Instituto, bem como em 2018 e 2019. Foi professor Visitante na Universidade Pablo de Olavide, Sevilha, como bolsista Erasmus Mundus na Faculdade de DIreito da Universidade Católica em Lisboa, na Faculdade de Direito da Universidade de Lisboa, no Mestrado em Direito Constitucional Europeu da Universidade de Granada, Espanha e na Universidade de Hamburgo, Alemanha. Desembargador aposentado do Tribunal de Justiça do Rio Grande do Sul. Advogado e Parecerista. E-mail: iwsarlet@gmail.com

\section{Jayme Weingartner Neto}

Doutor em Direito Público pela Pontifícia Universidade Católica do Rio Grande do Sul (2006). Mestre em Ciências Jurídico-Criminais pela Universidade de Coimbra (2000). Graduação em Direito pela Universidade Federal do Rio Grande do Sul (1990). Desembargador junto ao Tribunal de Justiça do Estado do Rio Grande do Sul (2012). Diretor da Escola Superior de Magistratura da AJURIS, biênios 2018/2019 e 2020/2021. Professor do Mestrado e Doutorado em Direito da Unilasalle/RS. E-mail: jayme.neto@unilasalle.edu.br

Pontifícia Universidade Católica do Rio Grande do Sul, Pós-Graduação em Direito - Mestrado e Doutorado.

Av. Ipiranga, 6681 - Prédio 11 - 10 andar - PUCRS

Porto Alegre - RS, 90619900 